\title{
Subjective Well-Being Perawat Yang Bekerja Di RS Jiwa Prof. Dr. Soerojo Magelang
}

\author{
Desi \\ Program Studi Ilmu Keperawatan, Fakultas Kedokteran dan Ilmu Kesehatan \\ Universitas Kristen Satya Wacana \\ desi@staff.uksw.edu \\ Tanti \\ Program Studi Ilmu Keperawatan, Fakultas Kedokteran dan Ilmu Kesehatan \\ Universitas Kristen Satya Wacana \\ Tantijes32@gmail.com \\ Yulius Yusak Ranimpi \\ Program Studi Sosiologi Agama, Fakultas Teologi \\ Universitas Kristen Satya Wacana \\ yulius.ranimpi@staff.uksw.edu
}

\begin{abstract}
Living a happy life is everyone's dream. Happiness in psychology is termed Subjective Well-Being (SWB). SWB is a cognitive evaluation (life satisfaction) and affective (positive and negative effects). Nurses need to have a high Subjective Well-being in order to maximize the service of nurses in hospitals. The purpose of this study was to determine the SWB level of nurses working in mental hospitals RS. Dr. Soerojo Magelang. The method used is descriptive quantitative survey approach using a self-evaluation questionnaire that has been patented (has been adapted, modified, and changed into Indonesian). The self-evaluation questionnaire includes an adaptation of the Scale of Positive and Negative Experience (SPANE) and The Satisfaction With Life Scale (SWLS) questionnaire. Data were processed using SPSS to test variables with a significance level of 0.05. For the level of well-being in the measurement of affect (positive and negative), 142 (54.0\%) respondents often experience positive affect and in the measurement of life satisfaction, as many as 156 (59.3\%) have high life satisfaction.
\end{abstract}

Keyword : affects; life satisfaction; nurses; subjective well-being 


\begin{abstract}
Abstrak
Menjalani hidup bahagia merupakan dambaan setiap orang. Kebahagiaan dalam ilmu psikologi diistilahkan sebagai Subjective Well-Being (SWB). SWB merupakan evaluasi kognitif (kepuasan hidup) dan afektif (afek positif dan negatif). Perawat perlu memiliki Subjective Well-being yang tinggi guna memaksimalkan pelayanan di rumah sakit. Tujuan dari penelitian ini ialah untuk mengetahui tingkat SWB perawat yang bekerja di RS jiwa RS. Jiwa Prof. Dr. Soerojo Magelang. Metode yang digunakan ialah kuantitatif deskriptif dengan pendekatan survei menggunakan kuesioner evaluasi diri yang sudah paten (sudah di adaptasi, dimodifikasi, dan diubah ke dalam bahasa indonesia). Kuesioner evaluasi diri meliputi adaptasi kuesioner Scale of Positive and Negative Experience (SPANE) dan The Satisfaction With Life Scale (SWLS). Data diolah menggunakan SPSS untuk menguji variabel dengan taraf signifikansi 0.05. Untuk tingkat well-being pada pengukuran afek (positif dan negatif), sebanyak 142 (54,0 $\%)$ responden sering mengalami afek positif dan pada pengukuran kepuasan hidup, sebanyak 156 (59,3\%) memiliki kepuasaan hidup yang tinggi.
\end{abstract}

Kata kunci : afek; kepuasan hidup; perawat; subjective well-being

\title{
Pendahuluan
}

Setiap orang menginginkan kesejahteraan (well-being) di dalam hidupnya, sebagaimana menurut Ningsih (dalam Rohmad, 2014) bahwa setiap orang memiliki harapan-harapan yang ingin dicapai guna pemenuhan kepuasan dalam kehidupannya. Well-Being sendiri dapat diartikan sebagai suatu keadaan positif yang memungkinkan seseorang, kelompok, ataupun suatu negara menjadi sejahtera. Diener (2009) menuliskan bahwa dalam konteks individu, well-being mengacu pada keadaan psikologis, fisik dan sosial yang positif sehingga setiap individu dapat menjalankan fungsi kehidupannya secara baik dan optimal. Konsep well-being meliputi kebahagiaan (happiness) yang dalam psikologi positif diistilahkan dengan Subjective Well-Being (SWB) yang mana SWB sendiri merupakan evaluasi diri individu melalui aspek kognitif dan afektif. Aspek kognitif yang dinilai meliputi kepuasan hidup (life satisfaction) seseorang baik di masa lampau, sekarang ataupun hal-hal yang ingin dicapai di masa mendatang (Diener, 2009). Dari penjelasan tersebut dapat disimpulkan bahwa evaluasi dan penilaian tentang kualitas hidup atau kepuasan hidup individu dinilai secara 
keseluruhan. Kepuasan hidup yang dimaksud berupa keadaan sejahtera atau kepuasaan hati yang merupakan kondisi hati yang menyenangkan, bila kebutuhan dan harapannya terpenuhi (Hurlock, 2009).

Berikutnya adalah kriteria individu dalam SWB yaitu dari aspek afektif dalam SWB. Aspek afektif dalam SWB ini terdiri dari afek positif dan afek negatif. Afek positif berarti seseorang yang memiliki emosi positif (sifat yang menyenangkan) sedangkan afek negatif berarti sebaliknya. Tanda-tanda seseorang dengan afek positif yaitu seseorang yang menyenangkan (sukacita dan kasih sayang) sedangkan afek negatif ditandai dengan seseorang yang memiliki emosi negatif yang sering dan berkepanjangan bahkan tidak menyenangkan. Bentuk utama dari reaksi negatif atau tidak menyenangkan itu adalah kemarahan, kesedihan, kecemasan dan kekhawatiran, stres, frustrasi, rasa bersalah, rasa malu, dan iri hati.

Ada beberapa hal yang dapat mempengaruhi well-being atau SWB seseorang diantaranya adalah usia. Individu yang berusia dewasa atau produktif cenderung memiliki skor well-being yang tinggi dalam hal mengalami pertumbuhan pribadi yang artinya mereka sudah melewati tahap-tahap perkembangan hidup dan menyadari tentang potensi-potensi diri yang sudah dilakukan dalam menjalani maupun mengalami pertumbuhan dan perkembangan hidup serta cenderung memiliki kemampuan penguasaan lingkungan dan otonomi dalam dirinya (Desi, 2017).

Selain daripada itu SWB seseorang dipengaruhi oleh jenis kelamin. Penelitian Ryff dan Keyes (1995) menunjukkan wanita lebih memiliki skor SWB yang tinggi dibanding laki-laki. Ini menjadi salah satu aspek bahwa wanita dapat membangun well-being mereka dengan menjalin hubungan baik dengan orang di sekitar. Hubungan dan relasi yang merupakan salah satu komponen dalam kesehatan mental seseorang sehingga kesehatan mental juga berperan dalam wellbeing.

Seperti yang sudah dijelaskan di atas, bahwa wanita lebih memiliki subjective well-being yang tinggi daripada laki-laki. Untuk itu dapat dinyatakan bahwa setiap individu yang memiliki subjective well-being yang tinggi ternyata 
bisa membuat individu tersebut merasa bahagia dan senang dengan teman dekat dan keluarga. Individu tersebut juga kreatif, optimis, pekerja keras, tidak mudah putus asa, dan tersenyum lebih banyak daripada individu yang menyebut dirinya tidak bahagia (Nurhidayah \& Rini, 2012) dan (Rohmad, 2014).

Pada faktor pekerjaan diatas, Argyle dalam Oktavinur dan Fikri (2017) mendefinisikan bahwa umumnya orang yang bekerja akan lebih memiliki kebahagiaan yang tinggi dibandingkan dengan mereka yang tidak bekerja. Faktor sosiodemografi lainnya yang juga mempengaruhi well-being adalah sosial ekonomi. Hal itu yang menunjukan bahwa terdapat hubungan antara kebahagiaan dan sosial ekonomi. Wenas (2015) menjelaskan dalam penelitiannya bahwa sebagian besar responden termasuk yang ditelitinya masuk dalam kategori sosial ekonomi tinggi yaitu 54 responden atau $(60,0 \%)$. Dari hasil penelitian tersebut dinyatakan sebagian besar responden yang ditelitinya dapat dinyatakan bahagia serta dengan adanya sosial ekonomi yang tinggi segala sesuatu yang menjadi kebutuhan masyarakat akan terpenuhi dan masyarakat akan mengalami kesejahteraan.

Selain itu, Weiten (2008) juga menjelaskan bahwa pernikahan mempengaruhi SWB seseorang. Menurutnya orang yang sudah menikah cenderung lebih bahagia jika dibandingkan dengan orang yang single atau cerai. Pernikahan akan membuat individu mendapatkan kebahagiaan dan kepuasan hidup (Listian \& Alhamdu, 2016). Bentuk dari kepuasaan hidup yang dirasakan adalah afek positif atau emosi yang menyenangkan seperti perasaan bahagia (Alhamdu, 2015). Selain dipengaruhi oleh sosiodemografi, SWB juga dipengaruhi oleh kondisi kesehatan (Sahusilawane, 2017). Menurut Dewanto (dalam Sahusilawane, 2017) penurunan kesehatan dan fungsi fisik seseorang menyebabkan penurunan kesejahteraan. Penelitian yang dilakukan di Kabupaten Sidoarjo menggambarkan bahwa kondisi fisik yang terganggu membuat individu terbatas dalam melakukan aktivitas yang berhubungan dengan diri sendiri maupun aktifitas sosial (Aini dan Aisyah, 2013). Kesejahteraan dapat didukung oleh kesehatan fisik yang baik. Apabila kesehatan fisik berada dalam kondisi buruk, maka akan meningkatkan perasaan sedih, patah semangat terhadap masa depan, 
serta mengalami penurunan kepercayaan diri (Sujana, 2015). Hal inilah yang menjadi alasan bahwa setiap individu mempunyai hak untuk memperoleh kesehatan yang sama melalui perawatan yang adekuat untuk mencapai subjective well-being, salah satunya adalah kesehatan mental (Krisnawati, 2013).

Setiap individu penting untuk mencapai kesehatan mental termasuk perawat yang bekerja di Rumah Sakit Jiwa atau perawat yang menangani pasien gangguan jiwa. Bagi perawat jiwa atau perawat jaga, menjaga tubuh dan pikiran (kesehatan mental) untuk tetap sehat adalah hal yang harus dilakukan. Berhubungan dengan banyak pasien dan bekerja dengan sistem shift, diomeli pasien dan keluarga, serta tak jarang harus melayani pertanyaan pasien bisa mengakibatkan berbagai macam keluhan, sekaligus stres (Dwiputra 2019). Kondisi stres yang dialami oleh individu atau perawat dapat memunculkan perasaan yang tidak menyenangkan (Fitria dan Anggun, 2015). Ketidakmampuan dalam mengelola kondisi stres dan Perasaan tidak menyenangkan yang sering muncul dapat berdampak pada SWB perawat dan mempengaruhi penilaian perawat tersebut terhadap kepuasan hidup (Karasawa dkk, 2011). Penilaian terhadap kepuasan hidup yang menyertakan afek positif dan negatif merupakan salah satu indikator dari subjective well-being (Rumaningsih dan Mrirahayu, 2011).

Selain itu seorang perawat harus memiliki kemampuan untuk mendorong pasien berpikir positif dalam proses penyembuhan penyakit pasien karena perawat adalah ujung tombak dalam pelayanan kesehatan, harus optimis membawa kenyamanan kepada pasien, baik di dalam lingkup rumah sakit maupun di luar. (Sahusilawane, 2017).

Oleh karena itu penting bagi perawat untuk memiliki subjective well-being guna menjalankan peran tugas sebagai perawat secara optimal sesuai dengan tuntutan. Hal tersebut didukung oleh Pavot dan Diener (2004) yang menyatakan bahwa subjective well-being berdampak pada kualitas hubungan sosial, kehidupan kerja, dan kesehatan mental perawat. Individu dengan sujective well-being tinggi mudah dalam mengolah dan mempertahankan persahabatan, hubungan romantis, dan pernikahan. 
Menarik untuk diteliti bahwa subjective well-being menurut (Desi, (2017) sangat diperlukan oleh seorang perawat untuk bisa menjalankan peran dan tugasnya secara optimal sesuai dengan tuntutan serta dapat menjadi acuan bagi tiap individu untuk berproses lebih baik di masa yang akan datang dengan mempertahankan bahkan meningkatkan keadaan sejahtera yang sudah di capai.

Tujuan penelitian ini adalah upaya untuk mendeskripsikan tingkat kesejahteraan perawat yaitu dengan mengukur afek positif dan negatif (SPANE) serta kepuasaan hidup (SWLS). Pengukuran ini akan memampukan perawat untuk mengidentifikasi, menguraikan dan mengukur kondisi kesejahteraan subjektif.

\section{Metode}

Penelitian yang telah dilakukan pada bulan Februari 2018 di Rumah Sakit Jiwa di (RSJ) Prof. Dr. Soerojo Magelang dan telah mendapat ijin serta persetujuan dari komisi etik penelitian FKIK.

Pengambilan sampel menggunakan teknik total sampling pada populasi dengan memperhatikan strata (tingkatan) dalam populasi. Adapun teknik analisis data dalam penelitian ini dilakukan dengan analisis univariat untuk mendeskripsikan karakteristik dari variabel yang ada. Sementara kriteria inklusi responden dalam penelitian ini adalah perawat yang bekerja di bangsal keperawatan jiwa minimal 1 tahun dan memiliki jabatan sebagai perawat pelaksana, kepala ruang, dan perawat supervisi. Dari kriteria tersebut diperoleh 275 perawat, namun yang bisa menjadi responden hanya sebanyak 263 orang, karena ada beberapa perawat yang mendapat halangan, seperti cuti dan rotasi ruangan.

Metode yang digunakan dalam penelitian ini adalah metode kuantitatif yang dilakukan dengan teknik : survey self-administered questionnaire. Kuesioner ini sudah diadaptasi, dimodifikasi, diubah ke dalam Bahasa Indonesia, dan sudah diuji validitas dan reliabilitasnya sehingga bisa digunakan dalam pengambilan data. Kuesioner evaluasi diri yang digunakan meliputi SPANE (Scale of Positive and Negative Experience) dan SWLS (Life Satifaction Scale of Positive and Negative). Kuesioner SPANE yang digunakan dalam pengukuran 
SWB di sadur dari Diener dan Robert, (2009). Sementara untuk SWLS disadur dari Diener, Emmon, Larsen, dan Griffy (2009).

Dalam instrumen SPANE terdapat 12 pernyataan (6 pernyataan positif dan 6 pernyataan negatif) dan pemberian skornya berkisar 1-5. Pada skor SPANE, skor (16) - (25) dinyatakan selalu memiliki perasaan positif, (6) - (15) adalah sering, (-2) - (5) kadang-kadang, (-14) sampai (-3) jarang dan skor yang dinyatakan tidak pernah memiliki perasaan positif berkisar (-24) sampai (-15) sedangkan pada instrumen SWLS terdapat 9 pertanyaan. SWLS merupakan skala yang digunakan untuk mengukur tingkat kepuasaan hidup perawat baik dalam hal berpikir positif dan negatif. Kuesioner SWLS terdiri dari 9 pernyataan (4 positif dan 5 negatif). Interpretasi hasil pada SWLS yaitu $(38-45)$ dinyatakan memiliki perasaan sangat puas, $(31-37)$ dinyatakan sering memiliki perasan puas, $(24-$ 30) memiliki perasaan sedikit puas, $(17-23)$ memiliki perasaan cukup puas, $(9-$ 16) memiliki perasaan tidak puas, dan 5 - 9 memiliki perasaan sangat tidak puas.

Hasil uji reabilitas SPANE mempunyai nilai cronbach alpha sebesar 0,868 dengan nilai uji validitas berkisar 0,463 - 0,812 sedangkan SWLS sebesar 0,729 dengan nilai uji validitas berkisar 4,98 - 707. Hasil tersebut menunjukkan bahwa pertanyaan SPANE pada no 1 sampai dengan no 12 dan pernyataan SWLS adalah valid di karenakan R-hitung lebih besar dari R-tabel kecuali pada item SWLS terdapat 1 pernyataan yang tidak valid yaitu item no 5 . Hasil R-tabel tersebut di dapatkan dari signifikasi 0,05 dengan uji 2 sisi dan $\mathrm{N}$ (responden) $-2=$ 28, maka didapat nilai $r$ tabel adalah 0.3610. Data penelitian diolah menggunakan uji univariat. Selain mengisi dua kuesioner diatas, responden juga mengisi lembar profil sosiodemografi yang terdiri dari usia, jenis kelamin, pendidikan, jenis pekerjaan, pendapatan per bulan, dan status perkawinan. Adapun teknik analisis data dilakukan dengan analisis univariat. Analisis univariat digunakan untuk mendeskripsikan karakteristik dari variabel yang ada. 


\section{Hasil dan Pembahasan}

Di bawah ini dipaparkan hasil penelitian yang meliputi keadaan sosiodemografi, dan skor well-being (SPANE dan SWLS) yang terdiri dari perasaan positif negatif, dan kepuasaan hidup.

\section{A. Profil Sosiodemografi Responden}

Profil sosiodemografi dikumpulkan dengan tujuan untuk melihat latar belakang masing-masing dari responden. Sosiodemografi pada laki-laki lebih banyak dengan jumlah 147 responden (55,9 \%). Dari latar belakang pendidikan responden, yang paling dominan adalah mereka yang berpendidikan diploma yaitu meliputi sub variabel usia, jenis kelamin, pendidikan, pekerjaan, pendapatan perbulan dan status perkawinan. Hasil penelitian ini dipaparkan dalam Tabel 1.

\section{Tabel 1 Profil Sosiodemografi Responden}

\begin{tabular}{|c|c|c|}
\hline \multirow[t]{2}{*}{ Karakterisktik } & \multicolumn{2}{|c|}{ Jumlah Responden $(n=263)$} \\
\hline & (n) & $(\%)$ \\
\hline 1. 26-35 tahun & 91 & $34,6 \%$ \\
\hline 2. $36-45$ tahun & 92 & $35,0 \%$ \\
\hline 3. 46-55 tahun & 67 & $25,5 \%$ \\
\hline 4. 56-65 tahun & 13 & $4,9 \%$ \\
\hline 5. $>65$ tahun & 0 & $0 \%$ \\
\hline \multicolumn{3}{|l|}{ Jenis Kelamin } \\
\hline 1. Laki-laki & 147 & $55,9 \%$ \\
\hline 2. Perempuan & 116 & $44,1 \%$ \\
\hline \multicolumn{3}{|l|}{ Pendidikan } \\
\hline 1. Diploma & 173 & $65,8 \%$ \\
\hline 2. Sarjana (S1) & 31 & $11,8 \%$ \\
\hline 3. Profesi Ners & 57 & $21,7 \%$ \\
\hline 4. Pasca Sarjana & 2 & $0,7 \%$ \\
\hline \multicolumn{3}{|l|}{ Lama Bekerja } \\
\hline 1. 1-3 tahun & 9 & $3,4 \%$ \\
\hline 2. 3 tahun 1 bulan -6 tahun & 12 & $4,6 \%$ \\
\hline 3. 6 tahun 1 bulan -9 tahun & 45 & $17,1 \%$ \\
\hline 4. 9 tahun 1 bulan ke atas & 196 & $74,9 \%$ \\
\hline \multicolumn{3}{|l|}{ Status Perkawinan } \\
\hline 1. Belum Menikah & 7 & $2,7 \%$ \\
\hline 2. Menikah & 244 & $92,8 \%$ \\
\hline 3. Cerai hidup & 5 & $1,9 \%$ \\
\hline 4. Cerai Mati & 6 & $2,3 \%$ \\
\hline 5. Nikah Siri & 1 & $0,3 \%$ \\
\hline
\end{tabular}


Profil sosiodemografi dikumpulkan dengan tujuan untuk melihat latar belakang masing-masing dari responden. Sosiodemografi perawat dengan jenis kelamin laki-laki lebih banyak dengan jumlah 147 responden (55,9\%). Dari latar belakang pendidikan responden, yang paling dominan adalah mereka yang berpendidikan diploma yaitu meliputi sub variabel usia, jenis kelamin, pendidikan, pekerjaan, pendapatan perbulan dan status perkawinan. Hasil penelitian ini dipaparkan dalam tabel 1.1.

Berdasarkan tabel di atas, umur responden paling banyak berada dalam kelompok 36 - 45 tahun, yaitu sebanyak 92 responden $(35,0 \%)$, responden dengan jenis kelamin laki sebanyak 173 responden (65,8 \%). Lamanya responden bekerja paling banyak adalah 9 tahun 1 bulan ke atas yaitu sebanyak 196 responden $(74,9 \%)$. Penelitian ini juga menunjukkan bahwa responden dengan status menikah lebih banyak dari status yang belum menikah. Responden yang memiliki status perkawinan menikah sebanyak 244 responden $(92,8 \%)$ sedangkan yang belum menikah sebanyak 7 responden $(2,7 \%)$.

\section{B. Well-Being}

Well-Being merupakan suatu keadaan positif yang memungkinkan seseorang, kelompok, ataupun suatu negara menjadi sejahtera. Dalam konteks individu, well-being mengacu pada keadaan psikologis, fisik dan sosial yang positif sehingga individu tersebut dapat menjalankan fungsi kehidupannya secara baik dan optimal (Fiona, 2015). Well-being dalam penelitian ini dilakukan sebagai upaya mengevaluasi kondisi sejahtera perawat yaitu dengan mengukur afek positif dan negatif (SPANE) serta kepuasaan hidup yang terdiri dari pemikiran positif dan negatif (SWLS). Evaluasi ini tentunya dapat menjadi acuan bagi tiap individu untuk berproses lebih baik di masa yang akan datang dengan mempertahankan bahkan meningkatkan keadaan sejahtera yang sudah dicapai (Desi, 2017). Berikut adalah hasil penelitian ini: 


\subsection{Scale of Positive and Negative Experince (SPANE)}

Skala ini digunakan untuk mengukur afek positif dan negatif seseorang yang dirasakan selama 4 minggu terakhir, dan hasilnya dapat dilihat pada tabel berikut ini:

Tabel 2. Scale of Positive and Negative Experince (SPANE)

\begin{tabular}{clcc}
\hline & \multicolumn{1}{c}{$\begin{array}{c}\text { Skala } \\
\text { (SPANE) }\end{array}$} & \multicolumn{2}{c}{$\begin{array}{c}\text { Jumlah Responden } \\
(\mathbf{n = 2 6 3 )}\end{array}$} \\
\cline { 3 - 4 } & & 41 & $(\mathrm{n})$ \\
\hline 1. & Selalu mengalami perasaan positif & 142 & $15,6 \%$ \\
2. & Sering mengalami perasaan positif & 59 & $22,4 \%$ \\
3. & Kadang-kadang mengalami perasaan positif & 21 & $8,0 \%$ \\
4. & Jarang mengalami perasaan positif & 0 & $0 \%$ \\
5. & Tidak pernah mengalami perasaan positif & & \\
\hline
\end{tabular}

Berdasarkan tabel 2 dari 263 responden, sebagian besar, yaitu 142 responden $(54,0 \%)$ merasa sering mengalami perasaan positif. Sedangkan yang memiliki perasaan kadang-kadang mengalami perasaan positif sebanyak $59(22,4 \%)$. Data ini menujukkan bahwa sebagian besar responden sudah mengalami pengalaman memiliki perasaan positif secara ajeg.

\subsection{Satisfaction With Life Scale (SWLS)}

Skala ini merupakan skala yang digunakan untuk mengukur kepuasaan hidup seseorang.

Tabel 3. Hasil Uji analisis SWLS

\begin{tabular}{llcc}
\hline & & $\begin{array}{c}\text { Skala } \\
\text { (SWLS) }\end{array}$ & \multicolumn{2}{c}{$\begin{array}{c}\text { Jumlah Responden } \\
(\mathbf{n = 2 6 3 )}\end{array}$} \\
\cline { 3 - 4 } & & $(\mathrm{n})$ & $(\%)$ \\
\hline 1. & Memiliki perasaan sangat puas & 39 & $14,8 \%$ \\
2. & Memiliki perasaan puas & 156 & $59,3 \%$ \\
3. & Memiliki perasaan kurang puas & 65 & $24,7 \%$ \\
4. & Memiliki perasaan tidak puas & 3 & $1,2 \%$ \\
5. & Memiliki perasaan sangat tidak puas & 0 & $0 \%$ \\
\hline
\end{tabular}

Dalam perhitungan skala SWLS responden yang banyak memiliki perasaan puas adalah 156 responden atau 59,3\%, sedangkan yang sedikit memiliki perasaan tidak puas hanya 3 orang atau 1,2 \%. 


\section{Profil Sosiodemografi Responden}

Di bawah ini dipaparkan pembahasan yang meliputi sosiodemografi, Scale of Positif and Negative Experience (SPANE) dan Satisfaction with Life Scale (SWLS) yang terdiri dari afek negatif positif serta kepuasaan hidup.

Berdasarkan hasil penelitian yang dilakukan ditemukan bahwa jumlah perawat laki-laki lebih banyak dibanding jumlah perawat perempuan yaitu; 147 $(55,9 \%)$ berbanding $116(44,1 \%)$. Hal ini dikarenakan jumlah bangsal untuk pasien laki-laki lebih banyak dibanding dengan bangsal rawat perempuan. Dari hasil wawancara yang dilakukan pada tanggal 09 November 2018 dengan perawat spesialis di RSJ. Dr. Soerojo Magelang, dikemukakan bahwa pasien laki-laki dirawat oleh perawat laki-laki dan pasien perempuan dirawat oleh perawat perempuan. Hal ini berkaitan dengan etika perawatan terhadap gender yang sama, sehingga memudahkan dalam pemberian asuhan keperawatan, dan menjaga harkat martabat pasien serta menjunjung kenyaman pasien. Selain itu untuk menghindari tindakan asusila yang mungkin saja terjadi. Di samping itu juga dapat menciptakan suasana kedekatan emosional pasien agar tidak merasa canggung ketika berinteraksi dengan perawat dan mempermudah perawat dalam proses berlangsungnya komunikasi terapeutik (BST, 2017).

Dari kuesioner yang disebarkan dalam penelitian ini dari total keseluruhan 263 responden didapatkan hasil bahwa perawat yang bekerja di RSJ. Prof. Dr, Soerojo Magelang sebagian besar (65.8 \%) adalah lulusan Diploma Keperawatan, $11,8 \%$ adalah lulusan S1, Profesi Ners, dan $0.7 \%$ adalah lulusan S2. Tingginya lulusan perawat dengan pendidikan Diploma, akan sangat mempengaruhi pelayanan asuhan keperawatan. Sedangkan ilmu pengetahuan terus berkembang, untuk mengapai ilmu supaya dapat memberikan pelayanan kesehatan pada klien. Untuk itu Kementrian Kesehatan Republik Indonesia no 10 tahun 2015 membuat suatu kebijakan tentang standar pelayanan keperawatan di rumah sakit. Kebijakan yang di maksud adalah terkait pelayanan perawat kepada klien dengan cepat dan tepat sasaran serta perawat terus belajar, baik formal maupun non formal seperti belajar sendiri dari buku-buku atau jurnal terbaru guna menciptakan tenaga perawat profesional dan kompeten sesuai teknologi dan keperawatan 
perkembangan ilmu yang ada. Hasil diatas tentunya dapat menjadi masukan bagi instansi terkait untuk mewujudkan hak belajar perawat sesuai kode etik agar perawat terus mengembangkan dirinya untuk memberikan pelayanan yang profesional pula.

\section{Tingkat Well-being}

\section{Scale of Positif and Negative Experience (SPANE)}

Hasil SPANE dalam penelitian ini, menunjukkan bahwa sebagian besar responden mengalami perasaan positif yaitu sebanyak 142 orang atau sekitar 54,0 $\%$ dari total sampling. Perasaan positif selalu di rasakan karena responden ratarata masih dalam usia produktif. Individu yang tergolong dalam kategori usia produktif adalah individu yang memiliki pikiran yang matang dan hidup stabil, bisa menyesuaikan diri dengan perubahan, fleksibel serta mampu bekerja secara efisien (Hurlock, 1994).

Responden dengan usia produktif masih didominasi oleh responden berjenis kelamin laki-laki. Hal ini dimungkinkan terjadi karena laki-laki lebih mudah mengelola pola pikirnya untuk tetap positif, sehingga mampu mengontrol perasaan marah dengan baik sehingga membuatnya lebih nyaman (Dini, 2011). Jika seseorang mampu mengelola pola pikirnya dengan baik, ia dapat dikatakan sebagai pribadi yang lebih banyak memiliki afek positif sehingga dapat mengurangi afek negatif.

Dalam Sahusilawane (2017), jika seseorang memiliki perasaan positif lebih banyak dari pengalaman negatif ia akan hidup lebih sejahtera. Berpikir positif dan mengurangi pikiran negatif adalah hal yang dibutuhkan seseorang untuk mencapai kesejahteraan (SWB). Jika seseorang tidak memiliki pikiran positif dalam mengendalikan rasa amarah atau masalah yang dihadapinya, maka dapat menyebabkan dampak negatif seperti sedih dan berujung pada penyesalan.

Faktor selanjutnya yang mempengaruhi perasaan positif responden adalah lamanya ia bekerja. Menurut Afrilyan (2017) Semakin lama seseorang bekerja, semakin banyak pengalaman yang di dapat. Dari pengalaman tersebut individu bisa menyesuaikan diri sehingga mampu menghadapi setiap permasalahan 
termasuk dalam bidang pekerjaan yang di gelutinya dan dapat merasakan perasaan positif (nyaman) dalam pekerjaannya.

\section{Satisfaction with Life Scale (SWLS)}

Dari 263 total keseluruhan jumlah responden berdasarkan data SWLS yang didapat dalam penelitian ini adalah $74,1 \%$, responden merasa puas dengan pendapatan diatas Rp. 3.500.00 dan disertai tunjangan tambahan yang mereka terima/bulan. Menurut Setiawan \& Sutanto (2013) juga mengemukakan bahwa tingkat kepuasaan hidup seseorang dapat dipengaruhi oleh pendapatan/gaji yang diterimanya perbulan. Tentunya dengan pendapatan bulanan yang lebih besar dan pengeluaran perbulan yang lebih kecil, ini sangat mempengaruhi tingkat kepuasan seseorang dalam menunjang kebahagiaannya di dalam keluarganya.

Sedangkan $25.9 \%$ dari responden tersebut ada yang merasa tidak puas dikarenakan masih ada yang memiliki pendapatan perbulan di bawah $\mathrm{Rp}$. 2.500.000 karna sesuai dengan masa kerja yang belum begitu lama/ masih fressgraduate serta gaji yang diberikan juga disesuaikan dengan jenjang pendidikan yang diembannya. Selain daripada itu di karenakan sebagian besar responden yang sudah menikah. Individu yang sudah menikah lebih besar pengeluarannya di banding individu yang belum menikah. Di dalam Artikel ekonomi okezone (2017) menjelaskan tentang tinggi rendahnya pendapatan sangat mempengaruhi tingkat kepuasaan maupun ketidakpuasaan seseorang.

Di samping itu juga, lama kerjanya seseorang ikut berpengaruh dalam kenaikan gaji serta kenaikan jabatan juga mempengaruhi tingkat kepuasan seorang perawat.

Sebagian besar respoden yang bekerja di RSJ. Prof Dr. Soreojo Magelang memiliki lama kerja 9 tahun ke atas yaitu 196 (74,9\%) responden, sehingga pendapatan gaji yang diterima dapat memenuhi kebutuhan hidupnya sehari-hari. Oleh sebab itu, inilah yang menjadi alasan utama bahwa semakin tingginya pendapatan seseorang dapat mempengaruhi tingkat kebahagiaan dirinya, serta memiliki kesempatan yang lebih besar untuk memenuhi standar kebahagiaan menurut versi mereka tersendiri, termasuk dalam memenuhi kebutuhan hidup keluarga dan memberikan rasa kepuasan pada pasangan (Yorga, 2016). 


\section{Kesimpulan}

Berdasarkan hasil penelitian dan bahasan diatas dinyatakan bahwa sebagian besar responden atau perawat yang bekerja di Rumah Sakit Jiwa Prof. Dr Soerojo Magelang memiliki perasaaan positif dan memiliki perasaan puas yang tinggi yang mana perasaan positif dan perasaan puas itu dipengaruhi oleh beberapa faktor diantaranya adalah dipengaruhi usia yang produktif, lama kerja atau pengalaman kerja serta pendapatan yang diperoleh. Dengan demikian dapat disimpulkan bahwa perawat di Rumah Sakit Prof. Dr Soerojo Magelang memiliki kondisi SWB yang baik.

\section{Saran}

Faktor-faktor lain seperti budaya, spiritualitas, relasi dan dukungan sosial mungkin dapat memiliki hubungan dengan subjective well-being yang dalam penelitian ini tidak diujikan sehingga ini menjadi keterbatasan dalam penelitian ini. Untuk penelitian selanjutnya, diharapkan dapat menganalisis lebih lanjut terkait subjective well-being perawat dan kepuasaan kerja perawat berdasarkan faktor seperti budaya orang lain, sesuai derajat dan kedudukannya. Faktor budaya yang menjadi alasan untuk digali lebih dalam, guna mengetahui bagaiamana pengaruh budaya Jawa yang rukun dan hormat tersebut terhadap kondisi subjective well-being seseorang.

\section{DAFTAR PUSTAKA}

Afrilyan. B, (2017) Pengaruh Kompetensi, Pengalaman Kerja dan Penempatan Kerja, Terhadap Komitmen Organisasi PT. Wahana Meta Riau Di Pekanbaru. Fakultas Ekonomi, Universitas Riau, Pekanbaru Indonesia. Jurnal JOM Fekom, Vol. 4 No.1. hlm. 153-166.

Aini S. N dan Aisyah S N. (2013). Psychologicall Well-Being Penyandang Gagal Ginjal. Jurnal penelitian Psikologi. Program Studi Psikologi, Fakultas Dakwah IAIN Sunan Ampel Surabaya, Vol.4 No. 01.

Alhamdu. (2016). Subjective Well-Being Siswa Man 3 Palembang Yang Tinggal Di Asrama. Psikis: Jurnal Psikologi Islami, 1(1), 95-104. 
(BST, R, 2017)BST, R, S. (2017). Penerapan Komunikasi Terapeutik Nonverbal Perawat Dalam Penanganan Pasien Sakit Jiwa Di Rumah Sakit Khusus Daerah Provinsi Sulawesi Selatan (Studi Kasus Rumah Sakit Jiwa Dadi Makassar). Departemen Ilmu Komunikasi Fakultas Ilmu Sosial Dan Ilmu Politik Universitas Hasanuddin.

Desi. Ayub. P, dan Bagus, P, S, A. (2017). Well-being dan Strategi Koping; Studi Sosiodemografi di Getasan. Jurnal Ilmu Keperawatan dan Kebidanan, Vol. 9, No. hlm, 21-30.

Dini. (2011). Mengubah Amarah Jadi Positif. Di baca 20 November 2018.

Diener, E. Oishi, S. and Lucas, R. (2009). Subjective Well-Being: The Science of Happiness and Life Satisfaction: The oxford Handbook of Positive Psychology. Publication.

Fitria, W. A. dan Anggun, R. P. Hardiness dan Subjective Well-being pada perawat. Fakulltas Psikologi, Universitas Diponegoro. Jurnal Empati, Volume 4 (4), 73-74. anggrainiwidhy@gmail.com. 2015.

Hurlock, E. B. (1994). Psikologi Perkembangan, Suatu Pendekatan Sepanjang Rentang Kehidupan. jakarta: erlangga.

Hurlock, E. B. (2009). Psikologi Perkembangan. jakarta: erlangga.

Istiningtyas, L. (2014). Humor Dalam Kajian Psikologi Islam. Jurnal Ilmu Agama UIN Raden Fatah, 15(1), 37-59.

Karasawa, Churchan K B, Markus H R, Kitayama S S, Dienberg L G, Radler B T, Ryff, C. D. (2011). Cultural perspectives on aging and well-being: A comparison of Japan and the U.S. Int J Aging Hum Dev. 73 (1): 73.

Krisnawati, R . 2013. Kesejahteraan Subjective (Subjective Well-being) Buruh Pabrik PT. Laksana Teknin Makmur Kabupaten Bogor. Skripsi Fakultas Ilmu Pendidikan, Univeristas Pendidikan Indonesia.

Lubis, S. H. B. (2011). Hubungan Antara Self-Esteem Dengan Subjective WellBeing Karyawan Uin Syarif Hidayahtullah Jakarta (Skripsi).

Listian. P. S dan Alhamdu (2016). Subjective Well-being Pada Pasangan yang Menikah melalui Proses Ta'aruf. Jurnal Rap UNP, Vol. 7, No. 1, hlm. 78-79. 
Ningsih, D.A. 2013. Subjective Well-Being Ditinjau Dari Faktor Demografi (Status Pernikahan, Jenis Kelamin, Pendapatan). Jurnal Online Psikologi, Vol 1, No 02, di lihat 08 Juni 2018.

Nurhidayah, S dan Rini A. 2012. Kebahagiaan Lansia Di Tinjau Dari Dukungan Sosial Dan Spiritualitas. Jurnal Soul, Vol. 5, No. 2.

Oktrina, S. (2015) Subjective Well-being. Di akses 8/5/18

Oktavianur S, dan Fikri H. T. (2017). Kebahagiaan pada istri yang menjalani pernikahan jarak jauh. Jurnal PSYCHE 165 Fakultas psikologi, Vol 10, No 1, hlm 19-28.

Pavot, W. and Diener E. (2004). Findings on subjective well-being: Applications to public policy, clinical interventions, and educations. Dalam P. A Linley \& S. Joseph (Eds.), Positive psychology in pratice, 679-692. New Jersey: John Wiley \& Sons, Inc.

Peraturan Menteri Kesehatan Republik Indonesia Nomor 10 Tahun 2015. Standar Pelayanan Keperawatan Di Rumah Sakit Khusus Dengan Rahmat Tuhan Yang Maha Esa Menteri Kesehatan Republik Indonesia.

Permenkes. (2015). Standar Pelayanan Keperawatan di Rumah Sakit; Menteri Kesehatan Republik Indonesia.

Putra, D. (2019). Manfaat Meditasi untuk Perawat Jaga dan Manfaatnya.

Prasetia, Dimas et al. 2015. "Analisis Faktor Yang Mempengaruhi Pendapatan Tenaga Kerja Wanita Pada Industri Manik-Manik Di Desa Tutul Kecamatan Balung Kabupaten Jember ( Analysis of Factors Affecting Income Labor Women In Industry Handycraft In Tutul Village Subdistrict Jember Balung)."

Ramdan, I. M., \& Fadly, O. N. (n.d.). 2016. Analisis Faktor yang Berhubungan dengan Burnout pada Perawat Kesehatan Jiwa. 4.

Rohmad. (2014). Hubungan Antara Dukungan Sosial Dengan Kesejahteraan Subjektif Pada Mahasiswa. Skripsi. Psikologi Universitas Muhammadiyah Surakarta. Fakultas Psikologi.

Rumaningsih, dan Mrirahayu, 2011. Pengaruh Faktor Organisasional Pada Stres Kerja Para Perawat Dengan Pengalaman Kerja Sebagai Variabel Pemoderasi (Studi Pada Rumah Sakit Dr. Moewardi Surakarta). Jurnal Manajemen Bisnis Syariah, No. 02/Th.V/Agustus 2011, hal. 955-967. 
Ryff, C. D, Keyes, C, L. M. (1995). The structure of Psychology well-being revisited. Journal of Personality and Social Psychology, 69(4), 719-727.

Sartika, M. \& K., (2011). Kecamatan Gunungpati Semarang. Kerja, K., Puskesmas,

Sahusilawane L, Ranimpi, Y. Y, dan Desi. (2017). Hubungan antara Psychologycal Well-being Perawat dengan Psychologycal Well-being Pasien Anak, Jurnal Keperawatan Muhammdiyah Vol 2, No 2. ISSN : 2541-1390. E-ISSN : 2597-7539.

Sujana, Rima Christine. 2015. "Peningkatan Kesejahteraan Psikologis Pada Penderita Diabetes Mellitus Tipe 2 Dengan Menggunakan Group Positive Psychotherapy Improvement Of Psychological Well-Being In Patients With Type 2 Kesehatan Merupakan Hal Penting Dalam Hidup Manusia . Ketika Terke." 7 (2): 215-32.

Veenhoven R. (1996) The Study Of Life Satisfaction. In: Saris, W.E., Veenhoven, R., Scherpenzeel, A.C. \& Bunting B. (eds) 'A comparative study of satisfaction with life in Europe. Eötvös University Press.

Visakha. D (2011). Subjective Well-being. Di akses pada tanggal 16 November 2018.

Willdani. (2014). Subjective Well-being. http. repository.Usu.ac. id_bitstream_handle_123456789_33501_sequence=4.

Wenas, Gloria E, Henry Opod, and Cicilia Pali. 2015. "Hubungan Kebahagiaan Dan Status Sosial Ekonomi.” 3(April).

Weiten, W (2008). Psychology Themes and Variantions Breifer Version. USA. International. Student Edition.

Yorga. M (2015) Gajimu Bahagiamu: sebuah studi tentang kebahagiaan di kalangan profesional muda di indonesia.

Wicahyani, P.Y. 2013. Hubungan Penyesuaian diri dengan Kebahagiaan Perkawinan Istri Yang Tinggal dengan Ibu Mertua. Skripsi.Jurusan Psikologi, Fakultas Psikologi. Universitas Islam Negeri (UIN) Maulana Malik Ibrahim Malang. 